\title{
Is nutrition important in osteoporosis?
}

\author{
BY ANN PRENTICE
}

\author{
MRC Dunn Nutrition Unit, Downham's Lane, Milton Road, Cambridge CB4 IXJ
}

Osteoporosis is a crippling disease that affects millions of people worldwide. It is characterized by loss of bony tissue from the skeleton and deterioration of bone structure, and is associated with enhanced bone fragility and increased risk of fracture (Consensus Development Conference, 1991). Fragility fractures are most common at the wrist, spinal vertebrae and hip, although they can occur throughout the skeleton. The incidence of vertebral and hip fractures increases exponentially with advancing age while that of wrist fractures levels off after the age of 60 years (Compston, 1993).

Osteoporosis can be divided into two main categories (Melton \& Riggs, 1988; Compston, 1993). Type I (postmenopausal) typically occurs between ages 50-75 years and is more common in women than men (women:men 6:1 approximately). Fractures occur predominantly in trabecular bone, especially the distal radius (Colles' fracture) and the spinal vertebrae (crush fracture). Bone loss is accelerated, parathyroid hormone and 1,25-dihydroxycholecalciferol levels are reduced and $\mathrm{Ca}$ absorption is decreased. Oestrogen deficiency is regarded as the main pathogenetic factor of Type I osteoporosis, and hormone-replacement therapy is effective in reducing the bone loss and fracture risk associated with the menopause (Compston, 1993; Lindsay, 1993). Type II (senile) affects women and men over the age of 70 years (women:men approximately $2: 1$ ). Fractures occur in both cortical and trabecular bone, most commonly in the proximal femur (hip) and the spinal vertebrae (wedge fracture). Unlike Type I, bone loss in senile osteoporosis is not accelerated, and parathyroid hormone levels may be raised. There is increasing evidence that this hyperparathyroidism plays an important role in the pathogenesis of Type II osteoporosis and is secondary to vitamin D insufficiency (Compston, 1993; Khaw \& May, 1995).

Osteoporosis is a major public health problem in the UK, affecting one in three women and one in twelve men (National Osteoporosis Society, 1996). There are currently over three million sufferers in the UK, where approximately 60000 hip fractures, 50000 wrist fractures and at least 40000 vertebral fractures occur each year. Approximately one-third of orthopaedic beds in the UK are occupied by hip-fracture patients and treatment of osteoporosis costs the National Health Service in excess of $£ 750$ million per annum. Osteoporosis is often associated with considerable pain, disability and disfigurement, and can lead to premature death. Approximately $50 \%$ of elderly hip-fracture patients do not regain full independence, and $20 \%$ die within 6 months through complications connected with the fracture. Internationally, more than 1.5 million fractures occur annually, and this number is projected to increase 4 -fold by the year 2050 (Cooper et al. 1992).

\section{RISK FACTORS FOR OSTEOPOROSIS}

Low bone mineral mass is the main factor underlying osteoporotic fracture. The World Health Organization (1994) uses the following diagnostic criteria for the disease, based on bone mineral status expressed either as bone mineral content (BMC) or bone mineral density (BMD): normal, within 1 SD of young adult reference mean for the population; osteopenia, between -1 and -2.5 SD of the young adult mean; osteoporosis, more than 
-2.5 SD below the young adult mean. Assessments of bone mineral status are readily performed by techniques based on absorptiometry, such as dual-energy X-ray absorptiometry (DXA), quantitative computer tomography and ultrasound (World Health Organization, 1994). Other facets of bone quality, such as microarchitecture and turnover, are also likely to be important determinants of bone strength, but since, at present, they are less amenable to systematic study, their role in the pathogenesis of osteoporosis is unclear (Cooper \& Aihie, 1994).

Most osteoporotic fractures result from a fall, often from standing height (Compston, 1993; Cooper \& Aihie, 1994). A history of falls or dizziness, use of certain medications, alcohol abuse, poor eyesight, inadequate domestic lighting, dependency and immobility, are examples of factors that can increase the likelihood of falling and, hence, contribute to fracture risk. Age-related changes in neuromuscular function alter the way in which people respond during a fall, and this may account for the rise in hip fractures relative to wrist fractures among the elderly (Cooper \& Aihie, 1994). Measures to minimize the risk of falls, such as handrails and regular eyesight checks, or to reduce the impact of falls, such as floor coverings and hip protectors, can be useful in the prevention of osteoporotic fractures (Lauritzen et al. 1993).

\section{DETERMINANTS OF BONE MINERAL MASS}

Bone mineral status in later life is the net outcome of lifelong influences on skeletal mineral accretion and loss. Bone mineral is laid down throughout childhood, with the most rapid increase occurring during puberty, and deposition continues, at a slower rate, after growth in height has stopped (British Nutrition Foundation, 1989; Parsons et al. 1996). Peak bone mineral mass is achieved in early adult life (25-35 years of age), although the exact timing is not certain and may vary between different regions of the skeleton (Sowers \& Galuska, 1993). At older ages, bone is gradually lost from the skeleton in both men and women. For women, there is also a period of about $10-15$ years when bone loss is accelerated due to oestrogen withdrawal at the menopause, when more than one-third of bone is lost from the skeleton (Compston, 1993).

Bone is a living tissue, and is constantly undergoing breakdown and formation as part of the natural process of renewal and repair. As a result, any factor that influences the development of peak bone mineral mass or the loss of bone mineral in middle-age will affect later fracture risk. Many factors are thought to influence bone mineral status, including genetic inheritance, body build, hormonal concentrations, especially those of the sex hormones and calciotropic hormones, and lifestyle factors such as physical activity and diet.

Heritability studies have demonstrated that about $80 \%$ of the variation in bone mineral status is due to genetic factors (Eisman, 1995; Peacock, 1995). Allelic variations have been identified in a number of candidate genes that may be important in bone health, such as the vitamin D-receptor (VDR) gene, parathyroid-hormone-receptor gene, oestrogen-receptor gene, collagen genes, interleukin- 6 gene, and apolipoprotein $\mathrm{E}(\mathrm{ApoE})$ gene. However, at present the degree to which polymorphism in any of these genes affects bone mineral status, bone turnover or fracture risk is unclear and controversial (Eisman, 1995; Peacock, 1995). There is some recent evidence that gene-nutrient interactions may influence the importance of nutrition to bone health. For example, response at the lumbar spine to $\mathrm{Ca}$ supplements and vitamin D analogues has been related to VDR genotype (Ferrari et al. 1995; Matsuyama et al. 1995) and lipoprotein transport of vitamin $\mathrm{K}$ to bone is affected by ApoE genotype (Saupe et al. 1993). 


\section{NUTRIENTS AND BONE}

A large number of dietary components have been proposed as possible determinants of bone health and osteoporosis risk. In some instances, such as in the case of vitamin $\mathrm{K}$, vitamin $\mathrm{C}, \mathrm{Mg}, \mathrm{Cu}$ and $\mathrm{F}$, the biological action of the dietary constituent is at the level of bone itself; vitamin $\mathrm{K}$ is discussed later (p. 364) as an example of this type of nutrient. However, the putative importance of the majority of nutrients lies in their observed effects on the excretion or absorption of $\mathrm{Ca}$.

The adult human body contains about $1 \mathrm{~kg} \mathrm{Ca}$, and all but $1-2 \%$ is contained in bone (British Nutrition Foundation, 1989). In consequence, any factor that affects the amount of Ca retained by the body must alter total bone mineral mass. Nutrients that increase urinary $\mathrm{Ca}$ excretion, such as S-rich proteins, salt and caffeine, or that reduce net $\mathrm{Ca}$ absorption, such as fat, phytates and oxalates, are regarded as having a negative effect on bone. Conversely, nutrients that decrease $\mathrm{Ca}$ excretion, such as $\mathrm{B}$, or increase $\mathrm{Ca}$ absorption, such as sugars and $\mathrm{Ca}$, are regarded as beneficial. However, the situation is highly complex and the impact of these dietary constituents on long-term $\mathrm{Ca}$ balance and fracture risk is unclear. Some nutrients, phosphate for example, affect both net $\mathrm{Ca}$ absorption and excretion in such a way that there is little overall effect on Ca balance (Heaney \& Recker, 1994; Heaney et al. 1995). In addition, some dietary components, such as fat and phosphate, are digested or absorbed in the small intestine at a faster rate than $\mathrm{Ca}$, minimizing the potential negative effect on $\mathrm{Ca}$ absorbability (Heaney et al. 1995). Where measurable effects on $\mathrm{Ca}$ balance are observed, the magnitude is often small and can be compensated for by small increases in $\mathrm{Ca}$ intake. Caffeine, for example, reduces $\mathrm{Ca}$ retention by increasing $\mathrm{Ca}$ excretion and decreasing $\mathrm{Ca}$ absorption, but the small effect, equivalent to approximately $3 \mathrm{mg}$ Ca per cup of brewed coffee, is offset by the increased $\mathrm{Ca}$ intake associated with adding milk to the beverage (Barrett-Connor et al. 1994; Heaney et al. 1995). This may account for the observation that high caffeine intake is associated with greater post-menopausal bone loss only in women with low Ca intake (Harris \& Dawson-Hughes, 1994).

\section{ADAPTATION TO DIETARY CHANGES}

Interpretation of data relating diet composition to $\mathrm{Ca}$ balance is complicated by the likelihood that the body adapts to dietary changes by adjusting the amount of $\mathrm{Ca}$ absorbed from the gut and excreted in urine, sweat and gastrointestinal secretions. In general, only a proportion of the $\mathrm{Ca}$ in the diet is absorbed (about 30-40\%), some of the endogenous $\mathrm{Ca}$ secreted into the gut is re-absorbed, and only a very small proportion of the $\mathrm{Ca}$ filtered each day by the kidneys is excreted (approximately $2 \%$; Schaafsma, 1988). This provides considerable scope for the 'fine-tuning' of net absorption and excretion to ensure that the body retains sufficient $\mathrm{Ca}$ to meet its needs. Long-term control of $\mathrm{Ca}$ balance appears to occur primarily in the gastrointestinal tract rather than in the kidney. This is indicated by the fact that large increases in $\mathrm{Ca}$ intake produce only modest changes in urinary $\mathrm{Ca}$ excretion, equivalent to approximately $6 \%$ of the dose (Lemann et al. 1979; Prentice et al. 1995).

Adaptation to sustained dietary change can take several months to accomplish and the capacity to respond may vary between individuals. This was demonstrated by the detailed studies of Malm in the 1950s, where negative $\mathrm{Ca}$ balance associated with a decrease in $\mathrm{Ca}$ intake from 1000 to $500 \mathrm{mg} \mathrm{Ca} / \mathrm{d}$ gradually attenuated over the succeeding months, but zero balance, when $\mathrm{Ca}$ excretion had diminished to match intake, was restored only after a 
considerable period and was not achieved in some subjects by the end of the study (Malm, 1958; Kanis, 1991).

$\mathrm{Ca}$ release and uptake by the skeleton is a key aspect in the short-term control of $\mathrm{Ca}$ homeostasis. A rise in blood ionized-Ca concentration following a recent meal prompts a reciprocal response in circulating parathyroid hormone concentration (Lobaugh, 1996). This initiates changes in the renal and gastrointestinal handling of $\mathrm{Ca}$. In addition, the hormone elicits rapid uptake of $\mathrm{Ca}$ into a readily-exchangeable skeletal pool, followed by a second, slower phase of uptake into a skeletal compartment that turns over less rapidly (Lobaugh, 1996). The converse scenario occurs when blood ionized-Ca concentration falls.

The skeletal pool of slowly-exchangeable $\mathrm{Ca}$ corresponds to the $\mathrm{Ca}$ released and laid down during bone remodelling. Remodelling is the process whereby the skeleton undergoes continual renewal by a phased sequence of bone resorption and formation (Frost, 1973; Parfitt, 1980; Kanis, 1991). In the adult, $95 \%$ of bone turnover occurs by remodelling and approximately $10-15 \%$ of skeletal surfaces are in the process of being remodelled at any one time. Osteoclasts, the cells responsible for bone resorption, dissolve away a small, discrete portion of the surface. The resulting resorption cavity is refilled by the action of osteoblasts, the bone-forming cells. These lay down bone matrix (osteoid) which gradually becomes mineralized to form new bone. There is a strict chronological sequence of events, with recruitment of osteoblasts occurring some time after resorption, and with newly-formed bone mineralizing rapidly in the initial stages but more slowly thereafter. As a result, it takes many weeks for the entire process to be completed. During this time, there is a temporary net deficit of mineral in the volume of bone undergoing remodelling and, hence, in whole-body bone mineral (Parfitt, 1980; Kanis, 1991). It is estimated that, in normal adults, the reversible $\mathrm{Ca}$ deficit represents about $1.3 \%$ of total body bone $\mathrm{Ca}$, equivalent to approximately $14000 \mathrm{mg} \mathrm{Ca}$ (Table 1). Since bone turnover is greater in trabecular bone, the reversible Ca deficit is greatest in trabecular regions (about $4 \%$; Table 1). When resorption conditions vary, there is a transition period where the number or size of new resorption cavities is modified but restoration of existing resorption pits is maintained at the previous rate. This produces a quantitative change in the remodelling space, a corresponding alteration in the reversible $\mathrm{Ca}$ deficit, and results in a rise or fall in the total amount of mineralized tissue per unit volume of bone until a new steady-state is established (Kanis, 1991).

Table 1. Typical reversible calcium deficit associated with adult bone turnover (Based on Parfitt, 1980)

\begin{tabular}{|c|c|c|c|}
\hline & Cortical bone & Trabecular bone & Whole body \\
\hline Total bone $\mathrm{Ca}(\mathrm{mg})$ & 840000 & 210000 & 1050000 \\
\hline \multicolumn{4}{|l|}{ Reversible $\mathrm{Ca}$ deficit } \\
\hline Remodelling space*: $\mathrm{mg}$ & 3360 & 4200 & 7650 \\
\hline$\%$ total bone $\mathrm{Ca}$ & 0.4 & $2 \cdot 0$ & 0.7 \\
\hline Osteoid spacet: mg & 840 & 2100 & 2940 \\
\hline \% total bone $\mathrm{Ca}$ & 0.1 & $1 \cdot 0$ & $0 \cdot 3$ \\
\hline Low-density bonef: mg & 1050 & 2450 & 3500 \\
\hline$\%$ total bone $\mathrm{Ca}$ & 0.1 & 1.2 & 0.3 \\
\hline Total deficit: $\mathrm{mg}$ & 5250 & 8750 & 14000 \\
\hline$\%$ total bone $\mathrm{Ca}$ & 0.6 & $4 \cdot 2$ & $1 \cdot 3$ \\
\hline
\end{tabular}

* The volume of bone temporarily missing because of the time delay between bone resorption and formation. $\uparrow$ The volume of bone temporarily replaced by unmineralized protein matrix during bone formation.

$\ddagger$ The difference in mineralization between newly-formed bone ( $<6$ months old) and mature bone. 
Changes in the reversible $\mathrm{Ca}$ deficit act to minimize fluctuations in the $\mathrm{Ca}$ concentration of extracellular fluid caused by dietary influences (Kanis, 1991). An increase in $\mathrm{Ca}$ intake depresses bone turnover due to decreased activation frequency of osteoclasts, producing a lower rate of resorption, a reduction in the remodelling space and an increase in bone mineral content. Conversely, a decrease in $\mathrm{Ca}$ intake promotes osteoclast activation, increases bone turnover and decreases bone mineral. Changes in diet composition that affect $\mathrm{Ca}$ excretion or absorption would be expected to produce similar effects. This process may also underlie the physiological mobilization of $\mathrm{Ca}$ from the skeleton at times of high requirement, for example in early lactation (Prentice, 1994; Laskey et al. 1996). In some circumstances, dietary effects on the reversible Ca deficit can produce sufficiently large changes in bone mineral mass to be measurable by DXA and other precise measures of bone status (Kanis 1991, 1994a).

It is difficult to equate effects on the reversible $\mathrm{Ca}$ deficit with evidence of nutritional need or fracture risk. Ca supplements taken by post-menopausal women can produce a small increase in cortical BMD during the first months of treatment but bone loss generally retums to pre-supplementation rates within 1-2 years (Parfitt, 1980; Kanis, 1991). It is probable that increasing the dose further after a period of time would illicit another transient rise in bone mineral density. This suggests that, in this situation, the extra Ca acts pharmacologically on bone turnover rate, rather than corrects a nutritional deficiency in the classical sense (Kanis, 1991, 1994b). While temporary relief from bone loss may be beneficial for some post-menopausal women, the implications of a decrease in turnover for the bone health of other population groups, such as children and young adults, are not known.

\section{METHODOLOGICAL PROBLEMS}

The examination of the importance of diet to bone health is fraught with methodological and interpretative problems. As can be appreciated from the previous sections, studies that investigate the impact of diet composition or nutrient intakes on $\mathrm{Ca}$ balance are difficult to interpret unless they are conducted over a substantial period of time, which is rarely the case. In addition, there is considerable variation between individuals in their response to dietary change which makes extrapolation from small, detailed studies to the wider population unsafe. A decrease in the reversible $\mathrm{Ca}$ deficit as a result of some dietary modification may be detected as an increase in bone mineral status, but this may not necessarily translate into a benefit for bone health.

A further problem, that has been identified recently, is the widespread use of BMD, measured by DXA, as a measure of bone mineral status in epidemiological studies (Prentice et al. 1994). The problem arises because BMD, derived by dividing BMC by scanned bone area (BA), is not a true volumetric measurement and is highly correlated with BA at most skeletal sites. Failure to include BA in regression models can lead to spurious relationships emerging between BMD and size-dependent variables, such as nutrient intakes (Prentice et al. 1994). An efficient method of minimizing the potential for sizeconfounding is to include BA, body weight and height as independent variables in all regression models involving BMD (Prentice et al. 1994). BMI, a commonly-used measure in bone studies, is not effective in adjusting for size in this context (Cole \& Prentice, 1992; Prentice et al. 1994).

Although there have been a large number of observational studies that have investigated the association between diet and either $\mathrm{Ca}$ balance or bone mineral status, few are sufficiently detailed to provide a clear insight into nutrient requirements for optimal 
bone health and reduced fracture risk. For example, there have been two meta-analyses published in recent years exploring the relationship between bone mineral (generally BMD) and diet; both concluded that $\mathrm{Ca}$ intake is a significant determinant of bone status (Cumming, 1990; Welten et al. 1995). However, the magnitude of this effect is small, at about $1 \%$ of the population variance, and size-confounding must be suspected since none of the examined studies adjusted for bone size, and few normalized for body weight or height. The possibility of size-confounding, the difficulties associated with assessing energy and nutrient intakes accurately, and the likelihood that the absence of significant associations between bone status and specific nutrients tends to remain unreported, mean that much of the observational evidence relating bone mineral to specific dietary components is unreliable.

At present, the most useful information is provided by long-term intervention studies that examine the direct effects of dietary modification on bone mineral status or fracture incidence. Biochemical measurements of $\mathrm{Ca}$ and bone metabolism, especially functional indicators such as the bone turnover markers osteocalcin and deoxypyridinoline, provide supplementary data to explore possible mechanisms. There have been comparatively few such studies. Two nutrients are discussed in some detail to illustrate the current state of understanding in this area and the complexity of the issue: $\mathrm{Ca}$ and vitamin $\mathrm{K}$.

\section{CALCIUM}

Supplementation studies indicate that an increase in Ca intake for women during the early menopause is not effective in retarding bone loss from trabecular regions of the skeleton, including those most vulnerable to fracture in Type I osteoporosis (Riis et al. 1987; Dawson-Hughes et al. 1990; Elders et al. 1994). Reductions in cortical bone loss are observed during this period (Polley et al. 1987; Riis et al. 1987; Smith et al. 1989; Elders et al. 1994), but these are not as great as those achieved with hormone-replacement therapy (Riis et al. 1987) and tend not to be sustained (Kanis, 1991; Elders et al. 1994).

For older women, Ca supplementation reduces bone loss at the hip (Dawson-Hughes et al. 1990; Nelson et al. 1991; Reid et al. 1993; Chevalley et al. 1994; Prince et al. 1995), especially for subjects with low habitual Ca intake (Dawson-Hughes et al. 1990). Impressive reductions in hip-fracture incidence have been achieved in elderly women using a combination of $\mathrm{Ca}_{3}\left(\mathrm{PO}_{4}\right)_{2}$ and vitamin $\mathrm{D}$ supplements (Chapuy et al. 1992, 1994). Correction of poor vitamin D status and reduction in parathyroid hormone levels appear to be central to the mechanism of this effect. Increases in $\mathrm{Ca}$ intake have little effect on spinal-bone mineral in older women (Nelson et al. 1991; Chevalley et al. 1994; Prince et al. 1995).

There have been only a few published supplementation studies in children and adolescents that have examined bone mineral status (Johnston et al. 1992; Lloyd et al. 1993; Andon et al. 1994; Lee et al. 1994, 1995; Nowson et al. 1995). The emerging picture is that, particularly in pre-pubertal children, an increased $\mathrm{Ca}$ intake is associated with higher bone mineral status of approximately 1-5\% depending on the skeletal site (Table 2). Curiously, the effects observed in these studies were of similar magnitude, despite marked differences in the initial $\mathrm{Ca}$ intake of the volunteers and in the increase in $\mathrm{Ca}$ intake achieved by supplementation (Prentice, 1995). In addition, the interventions had the greatest impact in the early months of the supplementation period (Johnston et al. 1992; Nowson et al. 1995), and the effect disappeared after the supplement was withdrawn (Slemenda et al. 1993; Lee et al. 1995). These observations suggest that the increase in bone mineral was associated with a reduced reversible $\mathrm{Ca}$ deficit. This is compatible with 


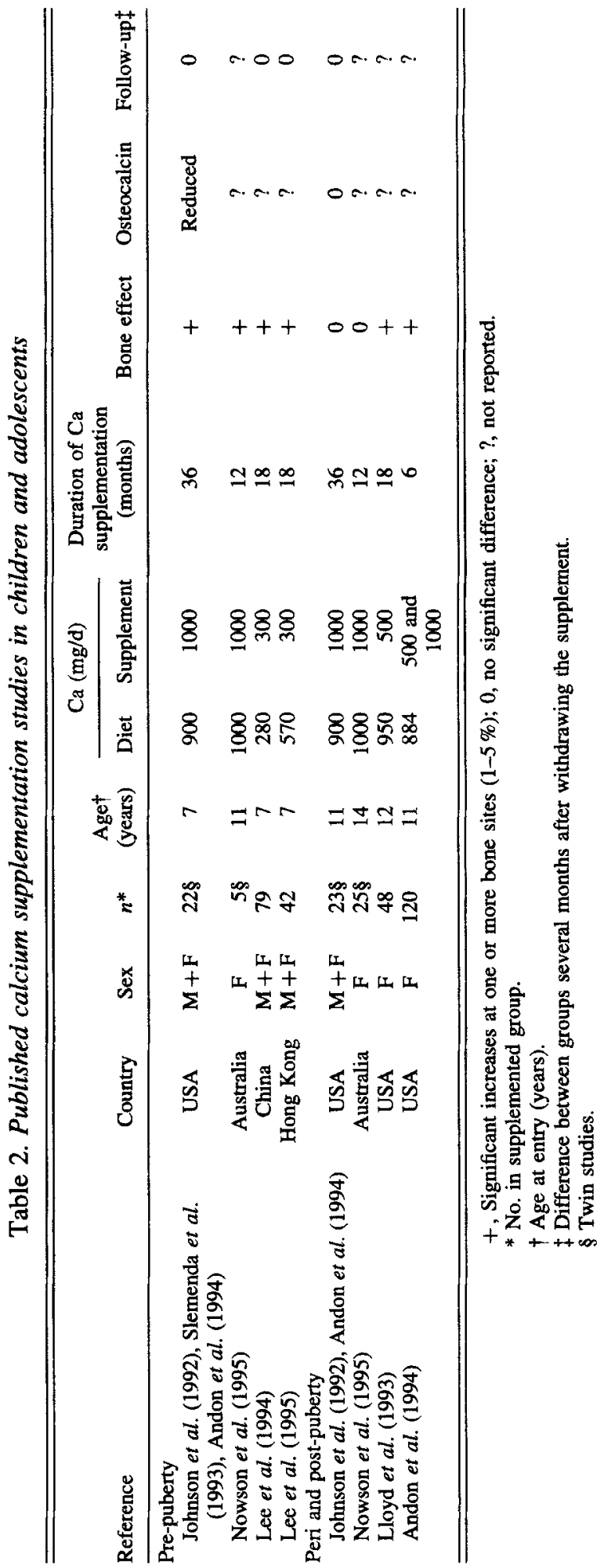


the size of the observed effects, and is supported by the account, in the one study that reported biochemical measurements, of lower circulating osteocalcin concentrations in supplemented children (Johnston et al. 1992; Slemenda et al. 1993). It would appear, therefore, that the higher level of $\mathrm{Ca}$ intake attained in these studies would have to be sustained indefinitely in order to achieve lasting effects on bone mineral status. However, whether reducing the rate of remodelling during childhood is beneficial for the acquisition of optimal peak bone mass and long-term bone health is not known.

On the basis of data such as these, there have been calls for large increases in recommended $\mathrm{Ca}$ intakes, particularly for older women and adolescents (National Institutes of Health, 1994). Whether the observed effects on bone mineral status associated with increases in $\mathrm{Ca}$ intake represent the correction of a nutritional deficiency is a matter of considerable controversy and debate (Kanis, 1994a). It may be that a step increase in Ca intake at certain vulnerable times may benefit the bone health of some individuals by the regulation of bone turnover, but the incorporation of this concept into the derivation of dietary reference values and nutritional guidelines will require a redefinition of the accepted criteria for dietary adequacy (Beaton, 1988; Department of Health, 1991). It is, however, worth reflecting that, on a global basis, osteoporotic fracture incidence is highest in populations with high $\mathrm{Ca}$ intakes, such as in Northern Europe (Royal College of Physicians, 1989), suggesting that low Ca intake per se is not a major predisposing factor for osteoporosis.

\section{VITAMIN K}

Vitamin $K$ is a cofactor of $\gamma$-glutamylcarboxylase, an enzyme involved in the posttranslational carboxylation of protein-bound glutamic acid residues (Vermeer et al. 1992). The resulting $\gamma$-carboxyglutamate residues (Gla) bind $\mathrm{Ca}$ ions avidly, and this is the basis of the biological activity of Gla-proteins. Hepatic Gla-proteins are important in blood coagulation; bone Gla-proteins, principally osteocalcin, are involved in the regulation of bone calcification (Vermeer et al. 1992).

Older people, patients with osteoporosis and newborn infants have a comparatively high proportion of circulating undercarboxylated osteocalcin which can be decreased by vitamin K supplements (1 mg/d; Jie et al. 1992; Szulc et al. 1994; Douglas et al. 1995; Vermeer et al. 1995). In addition, decreased serum levels of vitamin $\mathrm{K}$ have been reported in hip-fracture patients (Hart et al. 1984; Hodges et al. 1993) and there is limited evidence from Japan that vitamin $\mathrm{K}$ supplements at high doses $(45 \mathrm{mg} / \mathrm{d}$ ) may increase bone mineral status (Vermeer et al. 1995). To what extent vitamin $\mathrm{K}$ insufficiency is involved in the pathogenesis of osteoporosis is not known, but this question deserves further attention (Consensus Development Conference, 1993).

\section{POOR NUTRITIONAL STATUS}

It is important not to lose sight of the fact that poor nutritional status, in the broad sense, is a recognized risk factor for osteoporosis. Elderly patients with hip fracture are often malnourished on admission to hospital, and their prognosis is improved by the provision of dietary supplementation (Delmi et al. 1990). Low body weight and excessive dieting in younger women is associated with low bone mineral status and increased fracture risk, especially when normal gonadal function is disturbed (Frusztajer et al. 1990; Mazess et al. 1990; Prior et al. 1990). Poor vitamin D status in elderly people is associated with 
increased fracture risk, and dietary vitamin $\mathrm{D}$ provision becomes important in this agegroup because of decreased skin production of this vitamin (Department of Health, 1991).

\section{CONCLUDING REMARKS}

The issue of whether nutrition is important in the aetiology of osteoporosis is complex and unresolved. The unsatisfactory nature of much of the available data hampers the formulation of rational strategies based on diet and lifestyle for the prevention of osteoporosis and the reduction of fracture risk. A greater awareness of the methodological pitfalls inherent in many of the current techniques used to investigate this question, plus an increased emphasis on examining the underlying biological mechanisms, may help to simplify some of the apparent contradictions in the future.

\section{REFERENCES}

Andon, M. B., Lloyd, T. \& Matkovic, V. (1994). Supplementation trials with calcium citrate malate: Evidence in favor of increasing the calcium RDA during childhood and adolescence. Journal of Nutrition 124, 1412S1417S.

Barrett-Connor, E., Chang, J. C. \& Edelstein, S. L. (1994). Coffee-associated osteoporosis offset by daily milk consumption. Journal of the American Medical Association 271, 280-283.

Beaton, G. H. (1988). Nutrient requirements and population data. Proceedings of the Nutrition Society 47, 6378.

British Nutrition Foundation (1989). Calcium. London: British Nutrition Foundation.

Chapuy, M. C., Arlot, M. E., Delmas, P. D. \& Meunier, P. J. (1994). Effect of calcium and cholecalciferol treatment for three years on hip fractures in elderly women. British Medical Journal 308, 1081-1082.

Chapuy, M. C., Arlot, M. E., Duboeuf, F., Brun, J., Crouzet, B., Arnaud, S., Delmas, P. D. \& Meunier, P. J. (1992). Vitamin D3 and calcium to prevent hip fractures in elderly women. New England Journal of Medicine 327, 1637-1642.

Chevalley, T., Rizzoli, R., Nydegger, V., Slosman, D., Rapin, C.-H., Michel, J., Vasey, H. \& Bonjour, J.-P. (1994). Effects of calcium supplements on femoral bone mineral density and vertebral fracture rate in vitaminD replete elderly patients. Osteoporosis International 4, 245-252.

Cole, T. J. \& Prentice, A. (1992). Bone mineral measurements. British Medical Journal 305, 1223-1224.

Compston, J. (1993). Osteoporosis. In The Management of Common Metabolic Bane Disorders, pp. 29-62 [G. Campbell, J. Compston and A. Crisp, editors]. Cambridge: Cambridge University Press.

Compston, J. E. (1992). HRT and osteoporosis. British Medical Bulletin 48, 309-344.

Consensus Development Conference (1991). Diagnosis, prophylaxis and treatment of osteoporosis. American Journal of Medicine 90, 107-110.

Consensus Development Conference (1993). Diagnosis, prophylaxis and treatment of osteoporosis. American Journal of Medicine 94, 646-650.

Cooper, C. \& Aihie, A. (1994). Osteoporosis: recent advances in pathogenesis and treatment. Quarterly Journal of Medicine 87, 203-209.

Cooper, C., Campion, G. \& Melton, L. J. (1992). Hip fractures in the elderly: a world-wide projection. Osteoporosis International 2, 285-289.

Cumming, R. G. (1990). Calcium intake and bone mass: a quantitative review of the evidence. Calcified Tissues International 47, 194-201.

Dawson-Hughes, B., Dallal, G. E., Krall, E. A., Sadowski, L., Sahyoun, N. \& Tannenbaum, S. (1990). A controlled trial of the effect of calcium supplementation on bone density in post-menopausal women. New England Journal of Medicine 323, 878-883.

Delmi, M., Rapin, C.-H., Bengoa, J.-M., Delmas, P. D., Vasey, H. \& Bonjour, J.-P. (1990). Dietary supplementation in elderly patients with fractured neck of femur. Lancet 335, 1013-1016.

Department of Health (1991). Dietary Reference Values for Food Energy and Nutrients for the United Kingdom. London: H.M. Stationery Office.

Douglas, A. S., Robins, S. P., Hutchinson, J. D., Porter, R. W., Stewart, A. \& Reid, D. M. (1995). Carboxylation of osteocalcin in post-menopausal osteoporotic women following vitamin $\mathrm{K}$ and $\mathrm{D}$ supplementation. Bone 17 , 15-20.

Eisman, J. A. (1995). Vitamin D receptor gene alleles and osteoporosis: an affirmative view. Journal of Bone and Mineral Research 10, 1289-1293. 
Elders, P. J. M., Lips, P., Netelenbos, J. C., Van Ginkel, F. C., Khoe, E., Van Der Vijgh, W. J. F. \& Van Der Stelt, P. F. (1994). Long-term effect of calcium supplementation on bone loss in perimenopausal women. Joumal of Bone and Mineral Research 9, 963-970.

Ferrari, S., Rizzoli, R., Chevalley, T., Slosman, D., Eisman, J. A. \& Bonjour, J.-P. (1995). Vitamin-D-receptorgene polymorphisms and change in lumbar-spine bone mineral density. Lancet 345, 423-424.

Frost, H. M. (1973). Bone Remodelling and its Relationship to Metabolic Bone Disease. Springfield, $\mathrm{L}$ : Thomas.

Frusztajer, N. T., Dhuper, S., Warren, M. P., Brooks-Gunn, J. \& Fox, R. P. (1990). Nutrition and the incidence of stress fractures in ballet dancers. American Journal of Clinical Nutrition 51, 779-783.

Harris, S. S. \& Dawson-Hughes, B. (1994). Caffeine and bone loss in healthy post-menopausal women. American Joumal of Clinical Nutrition 60, 573-578.

Hart, J. P., Catterall, A., Dodds, R. A., Klenerman, L., Shearer, M. J., Bitensky, L. \& Chayen, J. (1984). Circulating vitamin K1 levels in fractured neck of femur. Lancet ii, 283.

Heaney, R. P. \& Recker, R. R. (1994). Determinants of endogenous fecal calcium in healthy women. Journal of Bone and Mineral Research 9, 1621-1627.

Heaney, R. P., Weaver, C. M. \& Barger-Lux, M. J. (1995). Food factors influencing calcium availability. In Nutritional Aspects of Osteoporosis ' 94 pp. 229-241 [P. Burckhardt and R. P. Heaney, editors]. Rome: AresSerono Symposia Publications.

Hodges, S. J., Akesson, K., Vergnaud, P., Obrant, K. \& Delmas, P. D. (1993). Circulating levels of vitamins K1 and $\mathrm{K} 2$ decreased in elderly women with hip fracture. Journal of Bone and Mineral Research 8, 1241-1245.

Jie, K.-S. G., Hamulyak, K., Gijsbers, B. L. M. G., Roumen, F. J. M. E. \& Vermeer, C. (1992). Serum osteocalcin as a marker for vitamin K-status in pregnant wornen and their new-born babies. Thrombosis and Haemostasis 68, 388-391.

Johnston, C. C., Miller, J. Z., Slemenda, C. W., Reister, T. K., Hui, S., Christian, J. C. \& Peacock, M. (1992). Calcium supplementation and increases in bone mineral density in children. New England Journal of Medicine 327, 82-87.

Kanis, J. A. (1991). Calcium requirements for optimal skeletal health in women. Calcified Tissue International 49, S33-S41.

Kanis, J. A. (1994a). Calcium nutrition and its implications for osteoporosis. Part 1. Children and healthy adults. European Journal of Clinical Nutrition 48, 757-767.

Kanis, J. A. (1994b). Calcium nutrition and its implications for osteoporosis. Part II. After menopause. European Journal of Clinical Nutrition 48, 833-841.

Khaw, K. T. \& May, H. (1995). Vitamin D and osteoporosis. Osteoporosis Review 3, 1-3.

Laskey, M. A., Hanratty, L. A. \& Prentice, A. (1996). Spine bone changes during lactation. In Current Research in Osteoporosis and Bone Mineral Measurement IV: 1996, p. 72 [E. F. J. Ring, D. M. Elvins and A. K. Bhalla, editors]. London: British Institute of Radiology.

Lauritzen, J. B., Petersen, M. M. \& Lund, B. (1993). Effect of external hip protectors on hip fractures. Lancet, 341, 11-13.

Lee, W. T. K., Leung, S. S. F., Cheng, J. C. Y., Wang, S. H., Xu, Y. C. \& Zeng, W.-P. (1995). Effects of calcium supplementation and subsequent withdrawal on bone acquisition of Chinese children. Proceedings of the 7 th Asian Congress of Nutrition F-61-03, p. 343. Beijing: Chinese Nutrition Society.

Lee, W. T. K., Leung, S. S. F., Wang, S. H., Xu, Y. C., Zeng, W.-P., Lau, J., Oppenheimer, S. J. \& Cheng, J. C. Y. (1994). Double-blind, controlled calcium supplementation and bone mineral accretion in children accustomed to a low-calcium diet. American Journal of Clinical Nutrition 60, 744-750.

Lemann, J., Adams, N. D. \& Gray, R. G. (1979). Urinary calcium excretion in human beings. New England Journal of Medicine 301, 535-541.

Lindsay, R. (1993). Prevention and treatment of osteoporosis. Lancet 341, 801-805.

Lloyd, T. M., Andon, M. B., Rollings, N., Martel, J. K., Landis, J. R., Demers, L. M., Eggli, D. F., Keiselhorst, K. \& Kulin, H. E. (1993). Calcium supplementation and bone mineral density in adolescent girls. Journal of the American Medical Association 270, 841-844.

Lobaugh, B. (1996). Blood calcium and phosphorus regulation. In Calcium and Phosphorus in Health and Disease, pp. 27-43 [J. J. B. Anderson and S. C. Garner, editors]. Boca Raton, Florida: CRC Press.

Malm, O. J. (1958). Calcium requirement and adaptation in adult man. Scandinavian Journal of Clinical Laboratory Investigation 10, Suppl. 26.

Matsuyama, T., Ishii, S., Tokita, A., Yabuta, K., Yamamori, S., Morrison, N. A. \& Eisman, J. A. (1995). Vitamin $\mathrm{D}$ receptor genotypes and bone mineral density. Lancet 345, 1238-1239.

Mazess, R. B., Barden, H. S. \& Ohlrich, E. S. (1990). Skeletal and body-composition effects of anorexia nervosa. American Journal of Clinical Nutrition 52, 438-441.

Melton, L. J. \& Riggs, B. L. (1988). Clinical spectrum. In. Osteoporosis, Etiology, Diagnosis, and Management, pp. 155-179 [B. L. Riggs and L. J. Melton, editors]. New York: Raven Press.

National Institutes of Health (1994). Optimal Calcium Intake. Bethesda, Maryland: National Institutes of Health.

National Osteoporosis Society (1996). Facts and Figures on Osteoporosis. Bath: National Osteoporosis Society. 
Nelson, M. E., Fisher, E. C., Dilmanian, T. A., Dallal, G. E. \& Evans, W. J. (1991). A 1-y walking program and increased dietary calcium in post-menopausal women: effects on bone. American Journal of Clinical Nutrition 53, 1304-1311.

Nowson, C. A., Green, R. M., Guest, C. S., Larkins, R. G., Sherwin, A. J., Kaymakci, B., Smid, M., Young, D., Hopper, J. L. \& Wark, J. D. (1995). The effect of calcium supplementation on bone mass in adolescent female twins. In Nutritional Aspects of Osteoporosis '94, pp. 169-175 [P. Burckhardt and R. P. Heaney, editors]. Rome: Ares-Serono Symposia Publications.

Parfitt, A. M. (1980). Morphologic basis of bone mineral measurements: transient and steady state effects of treatment in osteoporosis. Mineral and Electrolyte Metabolism 4, 273-287.

Parsons, T. J., Prentice, A., Smith, E. A., Cole, T. J. \& Compston, J. E. (1996). Bone mineral mass consolidation in young British adults. Journal of Bone and Mineral Research 11, 264-274.

Peacock, M. (1995). Vitamin D receptor gene alleles and osteoporosis: a contrasting view. Journal of Bone and Mineral Research 10, 1294-1297.

Polley, K. J., Nordin, B. E. C., Baghurst, P. A. \& Walker, C. J. (1987). Effect of calcium supplementation on forearm bone mineral content in post-menopausal women: a prospective sequential controlled trial. Journal of Nutrition 117, 1929-1935.

Prentice, A. (1994). Maternal calcium requirements during pregnancy and lactation. American Journal of Clinical Nutrition 59, Suppl., 477-483.

Prentice, A. (1995). Calcium requirements of children. Nutrition Reviews 53, 37-40.

Prentice, A., Jarjou, L. M. A., Cole, T. J., Stirling, D. M., Dibba, B. \& Fairweather-Tait, S. (1995). Calcium requirements of lactating Gambian mothers: effects of a calcium supplement on breast-milk calcium concentration, maternal bone mineral content and urinary calcium excretion. American Joumal of Clinical Nutrition 65, 58-67.

Prentice, A., Parsons, T. J. \& Cole, T. J. (1994). Uncritical use of bone mineral density in absorptiometry may lead to size-related artifacts in the identification of bone mineral determinants. American Journal of Clinical Nutrition 60, 837-842.

Prince, R. P., Devine, A., Dick, I., Criddle, A., Kerr, D., Kent, N., Price, R. \& Randell, A. (1995). The effects of calcium supplementation (milk powder or tablets) and exercise on bone density in post-menopausal women. Journal of Bone and Mineral Research 10, 1068-1075.

Prior, J. C., Vigna, Y. M., Schechter, M. T. \& Burgess, A. E. (1990). Spinal bone loss and ovulatory disturbances. New England Journal of Medicine 323, 1221-1227.

Reid, I. R., Ames, R. W., Evans, M. C., Gamble, G. D. \& Sharpe, S. J. (1993). Effect of calcium supplementation on bone loss in post-menopausal women. New England Joumal of Medicine 328, 460-464.

Riis, B., Thomsen, K. \& Christiansen, C. (1987). Does calcium supplementation prevent post-menopausal bone loss? New England Journal of Medicine 316, 173-177.

Royal College of Physicians (1989). Fractured Neck of Femur. London: Royal College of Physicians.

Saupe, J., Shearer, M. J. \& Kohlmeier, M. (1993). Phylloquinone transport and its influence on gammacarboxyglutamate residues of osteocalcin in patients on maintenance dialysis. American Journal of Clinical Nutrition 58, 204-208.

Schaafsma, G. (1988). Calcium in extracellular fluid homeostasis. In Calcium in Human Biology, pp. 241-259 [B. E. C. Nordin, editor]. London: Springer-Verlag.

Slemenda, C. W., Reister, T. K., Peacock, M. \& Johnston, C. C. (1993). Bone growth in children following the cessation of calcium supplementation. Journal of Bone and Mineral Research 8, S154.

Smith, E. L., Gilligan, C., Smith, P. E. \& Sempos, C. T. (1989). Calcium supplementation and bone loss in middle-aged women. American Journal of Clinical Nutrition 50, 833-842.

Sowers, M.-F. R. \& Galuska, D. A. (1993). Epidemiology of bone mass in pre-menopausal women. Epidemiologic Reviews 15, 374-398.

Szulc, P., Arlot, M., Chapuy, M. C., Duboeuf, F., Meunier, P. J. \& Delmas, P. D. (1994). Serum undercarboxylated osteocalcin correlates with hip bone mineral density in elderly women. Journal of Bone and Mineral Research 9, 1591-1595.

Vermeer, C., Knapen, M. H. J. \& Jie, K.-S. G. (1995). Increased vitamin K intake may retard post-menopausal loss of bone mass. In Nutritional Aspects of Osteoporosis '94, pp. 367-379 [P. Burckhardt and R. P. Heaney, editors]. Rome: Ares-Serono Symposia Publications.

Vermeer, C., Knapen, M. H. J., Jie, K. S. G. \& Grobbee, D. E. (1992). Physiological importance of extra-hepatic vitamin K-dependent carboxylation reactions. Annals of the New York Academy of Sciences 669, 21-33.

Welten, D. C., Kemper, H. C. G., Post, G. B. \& Van Staveren, W. A. (1995). A meta-analysis of the effect of calcium intake on bone mass in young and middle aged females and males. Journal of Nutrition 125, 28022813.

World Health Organization (1994). Assessment of Fracture Risk and its Application to Screening for Postmenopausal Osteoporosis. Geneva: WHO. 